Boletín de la Sociedad Geológica Mexicana

VOLUMEN 63, NÚM. 2, 2011, P. 333-343

\title{
New constraints on timing of Hidalgoan (Laramide) deformation in the Parras and La Popa basins, NE Mexico
}

\author{
Gary G. Gray ${ }^{1, *}$, Timothy F. Lawton ${ }^{2}$ \\ ${ }^{1}$ ExxonMobil Upstream Research Company, Houston, Texas 77027, USA. \\ ${ }^{2}$ New Mexico State University, Las Cruces, New Mexico 88003, USA. \\ *gary.g.gray@exxonmobil.com
}

\begin{abstract}
The Parras and La Popa basins of northeastern Mexico together contain at least three separate types of structures that were active during Maastrichtian through Early Eocene time. These structures include salt diapirs and salt welds, E-W trending anticlines detached within the Campanian Parras shale, and large NW-SE trending anticlines detached within the Jurassic salt layers. The oldest halokinetic structure, the La Popa salt weld, began to form by Late Aptian time. This structure is parallel to the later NW-SE contractional folds, but it pre-dates regional contraction. The earliest dated contractional structures in the Sierra Madre Oriental are E-W trending folds and faults found east of the La Popa syncline. These structures were active only briefly during the deposition of the lower Maastrichtian Muerto Formation. Very similar east-west structures in the northern Parras Basin contain growth strata of upper Maastrichtian and Paleocene age. Folding of upper Paleocene beds indicates that this shortening continued into the Eocene. Very Large amplitude NWSE trending anticlines in La Popa Basin also formed due to regional contraction, and they clearly re-fold the shallow-detached E-W set. Regional evidence suggests that all contractional deformation ceased around $40 \mathrm{Ma}$. Salt withdrawal may have continued after the cessation of contractional deformation. The contractional deformation in these basins is similar in structural style to the Sevier orogen in the U. S. A., but it is later and of shorter duration than the Sevier orogeny; it is time-equivalent to the Laramide orogeny, but it differs significantly from the Laramide structural style. Thus, the Mexican orogenic system differs from the U. S. A. orogens. This uniqueness was recognized by Guzmán and De Cserna (1963) who named this deformational event in Mexico the Hidalgoan orogeny.
\end{abstract}

Keywords: Laramide orogeny, Hidalgoan orogeny, Mexico, La Popa Basin, Parras Basin, Sierra Madre Oriental

\section{Resumen}

En las Cuencas de Parras y La Popa del noreste del México, contienen al menos tres estilos de estructuras distintas que estuvieron activas durante el Maastrichtiano hasta el Ecoeno temprano.. Estas estructuras incluyen diapiros de sal, soldaduras de sal, anticlinales orientados E-W, despegados en la lutita Parras del Campaniano, y grandes anticlinales orientados noroeste-sureste despegados en capas de sal del Jurásico. La estructura halocinética mas antigua, la soldadura de La Popa, inició su formación en el Aptiano tardio. Dicha estructura es paralela a pliegues de contracción NW-SE posteriores, pero precede a la contracción regional. Las estructuras de contracción más temprana fechadas en la Sierra Madre Oriental son pliegues y fallas de orientación Este-Oeste ubicados al oriente del sinclinal de La Popa. Estas estructuras estuvieron activas sólo brevemente durante la deposición de la Formación El Muerto del Maastrichtiano inferior. Estructuras muy similares E-W al norte de la Cuenca de Parras contienen estratos de crecimiento del Maastrichtiano superior y del Paleoceno. El plegamiento de las capas del Paleoceno superior indica que el acortamiento continuó en el Eoceno. Anticlinales de gran amplitud, orientados NW-SE en la Cuenca de La Popa se formaron también por la contracción regional y claramente repliegan las estructuras de desprendimiento someros orientadas $E$ - $W$. La evidencia regional sugiere que la deformación contraccional terminó hace alrededor de 40 Ma. La evacuación de la sal pudo haber continuado después del cese de la deformación 
contraccional. La deformación por contracción en estas cuencas es similar en estilo estructural a la orogenia Sevier en los E. U. A., pero es de ocurrencia posterior y de menor duración; es equivalente en tiempo a la orogenia Laramide, pero difiere significativamente de su estilo estructural. Por lo tanto, el sistema orogénico mexicano es diferente al de los E. U. A. Esta particularidad fue reconocida por Guzmán y De Cserna (1963), quienes nombraron este episodio deformacional la orogenia Hidalgoana en México.

Palabras Clave: Orogenia Laramide, orogenia Hidalgoana, Cuenca de La Popa, Cuenca de Parras, Sierra Madre Oriental.

\section{Introduction}

The greater Sierra Madre Oriental and adjacent Coahuila foldbelt of NE Mexico comprise one of the most spectacular fold provinces on Earth (Figure 1). This mountain belt is an extension of the Sevier-Laramide orogenic system into Mexico (De Cserna, 1956; Aranda-García, 1991). A thick succession of Upper Jurassic through lower Eocene strata (Figure 2) is fully involved in the deformation (De Cserna, 1971; Eguiluz de Antuñano, 2001; Gray et al., 2001), indicating a minimum early Cenozoic age for the contractional deformation. This timing is coeval with the latter part of the Laramide and Sevier events in the western United States (Craddock et al., 1988, Kulik and Schmidt 1988; Lawton and Trexler, 1991; Lawton et al., 1993). The style of deformation in the Mexican cordillera is predominantly thin-skinned, similar to the Sevier orogen in the U. S. A. (e.g., De Cserna, 1956; Armstrong, 1968; Padilla y Sánchez, 1985).

The timing of this orogenic event has been previously inferred from unconformities in adjacent basins (Prost et al., 1994; Prost and Aranda, 2001; Eguiluz de Antuñano, $2001)$ and from interpretations of syn-kinematic and postkinematic plutons in the Sabinas Basin (Chávez-Cabello, 2005). Although the onset of folding has not been previously constrained, these analyses place the end of contractional deformation in the late Eocene (41-38 Ma). Gray et al. (2001) attempted to date cooling related to the onset of this orogeny via apatite fission track analysis, but all apatites they examined were thermally reset in the mid-Tertiary. Gray et al. (2001) did obtain a $62 \mathrm{Ma} \mathrm{K} / \mathrm{Ar}$ age on fault gouge from a Hidalgoan thrust near Xilitla, San Luis Potosí, that was interpreted as the last stage of movement on this structure.

Contractional deformation created two distinct fold trends in the region (Figure 3; e.g., Soegaard et al., 2003). Very large northwest-southeast folds are parallel to the overall trend of the orogen and are detached within the underlying Middle Jurassic evaporites. Smaller east-west folds are detached within the Upper Cretaceous Parras shale. These two sets of structures are superimposed in the La Popa Basin. The primary purpose of this paper is to document this overprinting relationship and to present detailed evidence for the timing of the two sets of structures. In particular, we review evidence for the onset of contractional deformation in the early Maastrichtian.

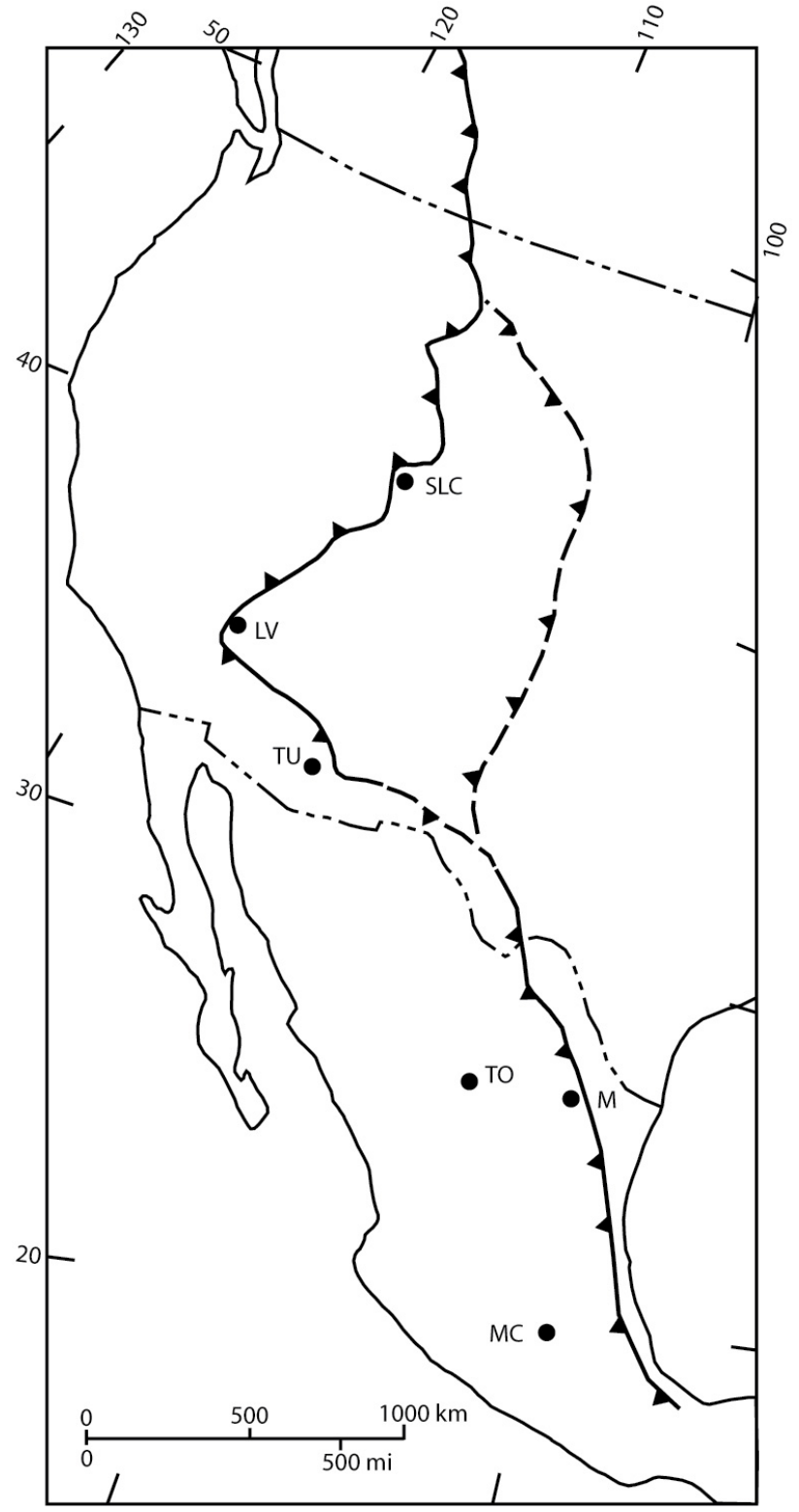

Figure 1. Extent of Sevier- and Laramide-style deformation in North America. The solid line is the approximate trace of the thin-skinned deformation front. This is dashed in southern Arizona and New Mexico, where it becomes a more complex boundary separating inverted extensional basins from the Colorado Plateau (e.g., Lawton, 2008). The completely dashed line marks the eastern limit of basement-involved deformation. Abbreviations: $\mathrm{SLC}=$ Salt Lake City; $\mathrm{LV}=$ Las Vegas; $\mathrm{TU}=$ Tucson; $\mathrm{TO}$ = Torreón; $\mathrm{M}=$ Monterrey; $\mathrm{MC}=$ Mexico City. Modified from Guzmán and De Cserna (1963), Campa-Uranga (1985), Drewes (1988), and Aranda-Garcia (1991). 

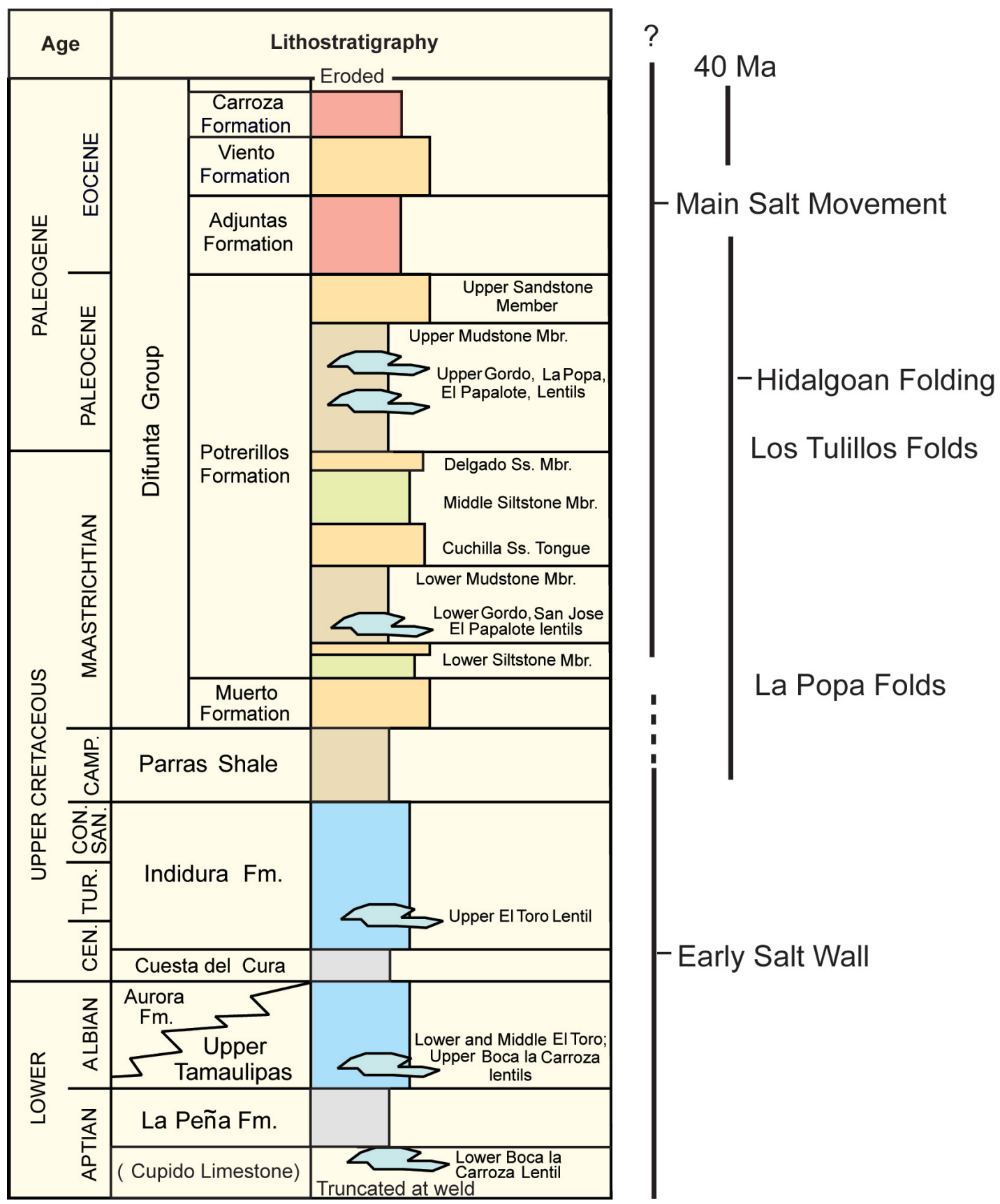

Figure 2. Stratigraphic chart for La Popa Basin. The irregular bodies in the lithostratigraphy column represent the age of carbonate lentils adjacent to the salt structures as labeled. The two vertical black bars on the right side of the diagram represent the age span of salt (left bar) and contractional (right bar) deformation. The left bar is divided into early salt wall phase and a later main phases. The labels "La Popa folds" and "Los Tulillos folds" are placed at the approximate times of activity, respectively. Modified after Lawton et al. (2001).

\section{Salt $v s$. 'Tectonic' structures}

The southern end of the Sabinas Basin encompasses a region of structures arising from the movement of underlying salt layers (Figure 3; Lawton et al., 2001; Rowan et al., 2003). Part of this region also has a significant accumulation of Cenozoic strata. The area with significant Cenozoic deposits is referred to as La Popa Basin (McBride et al., 1974; Laudon, 1984; Vega-Vera et al., 1989; Lawton et al., 2001). La Popa Basin is unique in the region in that it contains the only well-documented examples of salt diapirs and vertical salt welds in northern Mexico (Lawton et al., 2001). La Popa and the southern Sabinas Basin contain very large, northwest-trending folds. These folds have average lengths of $>60 \mathrm{~km}$, widths of $8 \mathrm{~km}$, and amplitudes in excess of $1 \mathrm{~km}$. The folds are detached within the Jurassic 


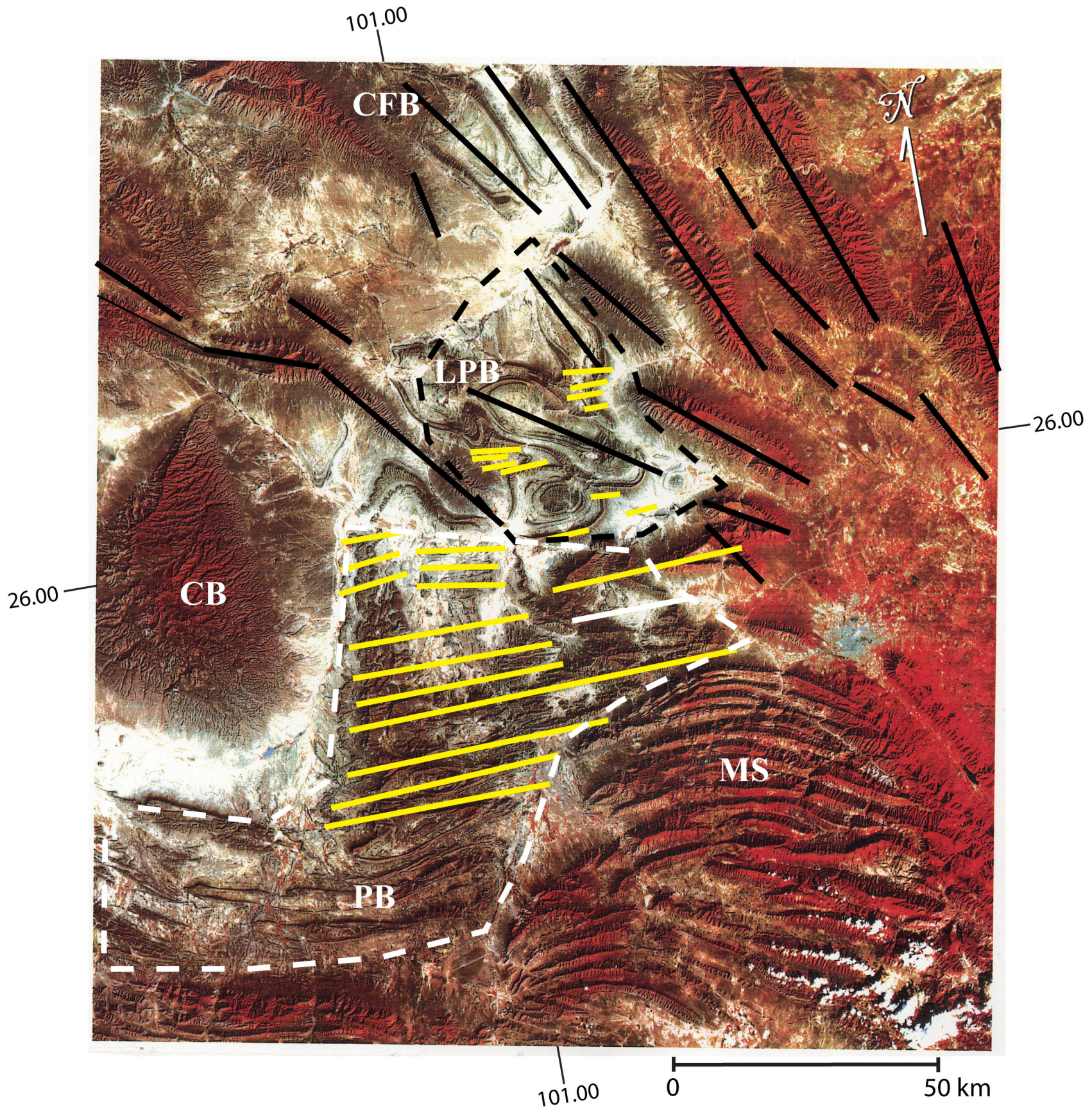

Figure 3. Landsat photograph of a portion of northeast Mexico. The La Popa Basin is outlined with a black dashed line, and the Parras Basin is outlined with a white dashed line. The northwest-trending folds of the Coahuila foldbelt are marked with black lines. The E-W trending folds of the Parras and La Popa basins are marked with yellow lines. The two structural trends have a significant area of overlap in La Popa Basin. Abbreviations: $\mathrm{CFB}=\mathrm{Coahuila}$ Fold Belt, LPB = La Popa Basin, $\mathrm{PB}=$ eastern Parras Basin, $\mathrm{CB}=$ Coahuila Block, MS = Monterrey salient. The area of Figure 4 is located between the eastern edge of the Coahuila Block and the Parras Basin.

Minas Viejas Formation. They trend parallel to analogous detachment folds in Lower Cretaceous carbonate strata that occupy the Coahuila folded province (Eguiluz de Antuñano, 2001; Chávez-Cabello, 2005).

Relatively thick Cenozoic strata are also present in the Parras Basin, although no salt structures are present (Figure 3; McBride et al., 1974; Ye et al., 1997; Soegaard et al.,
2003). These rocks are folded into E-W trending, northverging anticlines with larger amplitudes in the south that decrease to the north. Well exposed folds along the plunging eastern margin of the Coahuila uplift indicate that these structures are detached within the Campanian Parras Shale (Figure 5; Couch, 2005). In the Parras Basin, where no salt is known to exist, all of the structures are tectonic in origin 


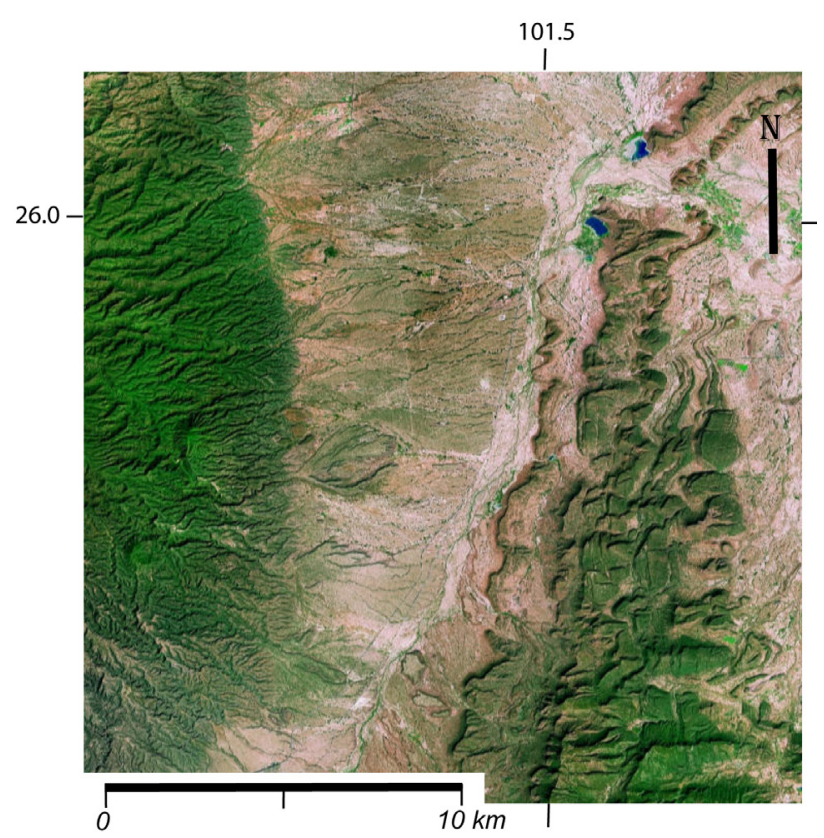

Figure 4. Detail from Landsat image showing the eastern margin of the Coahuila Block and adjacent Parras Basin. North is at the top of the figure. The gently dipping rocks on the left are Albian-Turonian platform carbonates on the Coahuila Block. The wavy rocks on the right are strongly folded Maastrichtian-Paleocene Difunta Group clastics. The recessive valley in between is occupied by the Campanian Parras Shale. This shale forms the detachment level between the planar Coahuila Block strata and the folded and faulted Difunta Group rocks.

and have northward vergence (Weidie and Murray, 1967; Dillman, 1985). In contrast, the salt diapirs and salt weld structures of the La Popa Basin are halokinetic in origin (Giles and Lawton, 1999, 2002; Rowan et al., 2003). To the north, in the Coahuila folded belt, northwest-trending salt-cored anticlines are clearly part of the regional, northeast-directed contractional deformation (Eguiluz de Antuñano, 2001). The northwest-trending folds in La Popa and Sabinas basins are interpreted to be detached on salt, and to be cored by salt. Although the role of contractional tectonics in forming the large northwest-trending folds in La Popa Basin is not clear, the similarity of fold trends in the La Popa and Sabinas basins suggests that the La Popa folds are largely the result of regional shortening.

\section{Evidence for the timing of salt structures}

The onset of salt movement in La Popa Basin is primarily determined from growth relationships adjacent to the salt bodies. The most obvious growth strata are localized shoaling carbonate bodies, named lentils by McBride et al. (1974). These lentils are generally composed of bioclastic limestone near the salt bodies, and become more carbonate mud-rich as they thin away from the salt. They are interpreted to represent deposition on localized bathymetric highs related to the upward movement of salt
(Giles and Lawton, 2002; Rowan et al., 2003). The oldest recognized lentil is Aptian (Lawton et al., 2001) adjacent to the La Popa salt weld. The lentils range from Aptian to early Eocene, with an apparent increase in number (as currently exposed in the basin) in the upper Maastrichtian through Paleocene section.

The large northwest-southeast trending folds that characterize La Popa Basin, in particular the El Gordo anticline, appear to be younger than the onset of diapirism, although they too are interpreted to be cored by salt (Lawton et al., 2001; Rowan et al., 2003). Weislogel (2001) demonstrated that the Maastrichtian Muerto Formation thins in proximity to the El Gordo diapir, yet maintains constant thickness across the adjacent northwest-trending El Gordo anticline, indicating that the diapir predates and the anticline post-dates deposition of the Muerto Formation. Hon (2001) demonstrated that the Muerto Formation onlaps the margin of the La Popa weld, but does not thicken into the adjacent northwest-trending La Popa syncline likewise indicating post-Muerto Formation onset of shortening (Figure 5). Druke (2005) documented growth geometries within the La Popa syncline in strata of the upper Maastrichtian Potrerillos Formation (Figure 6). Thus, the La Popa salt weld, with lentils as old as Aptian, is the oldest documented salt structure in the basin. The El Gordo diapir is also an early structure (Weislogel, 2001). The oldest salt rise associated with the El Papalote diapir can only be dated as late Maastrichtian due to lack of exposure of older units. On the basis of the data described above, the earliest reliable age for the northwest-southeast folding away from the $\mathrm{La}$ Popa weld is late Maastrichtian.

Evidence for the end of salt deformation in La Popa Basin varies depending upon the particular salt structure in question. Local thinning relationships demonstrate that the El Papalote diapir continued to rise during deposition of the Paleocene upper sandstone member of the Potrerillos Formation (Shelley and Lawton, 2005), but ceased to move during deposition of the lower Eocene Adjuntas Formation (Gray, unpublished data). Lower Eocene Viento beds are folded by the El Gordo diapir, so salt movement there continued later into the early Eocene, but that is the end of the sedimentary record. The youngest unit preserved in the basin is the early Eocene Carroza Formation (Vega-Vera et al., 1989), which is only present in a mini-basin directly southwest of the La Popa weld. There are no preserved early Eocene beds on the north side of the weld, but projection of the top Paleocene surface onto the weld, from both sides, indicates an offset of at least $1 \mathrm{~km}$. This post-early Eocene displacement is approximately $30 \%$ of the total slip along this weld and suggests that salt movement along the La Popa weld continued well into the Tertiary.

\section{Evidence for timing of contractional structures}

The first indication of orogeny in the Parras-La Popa 


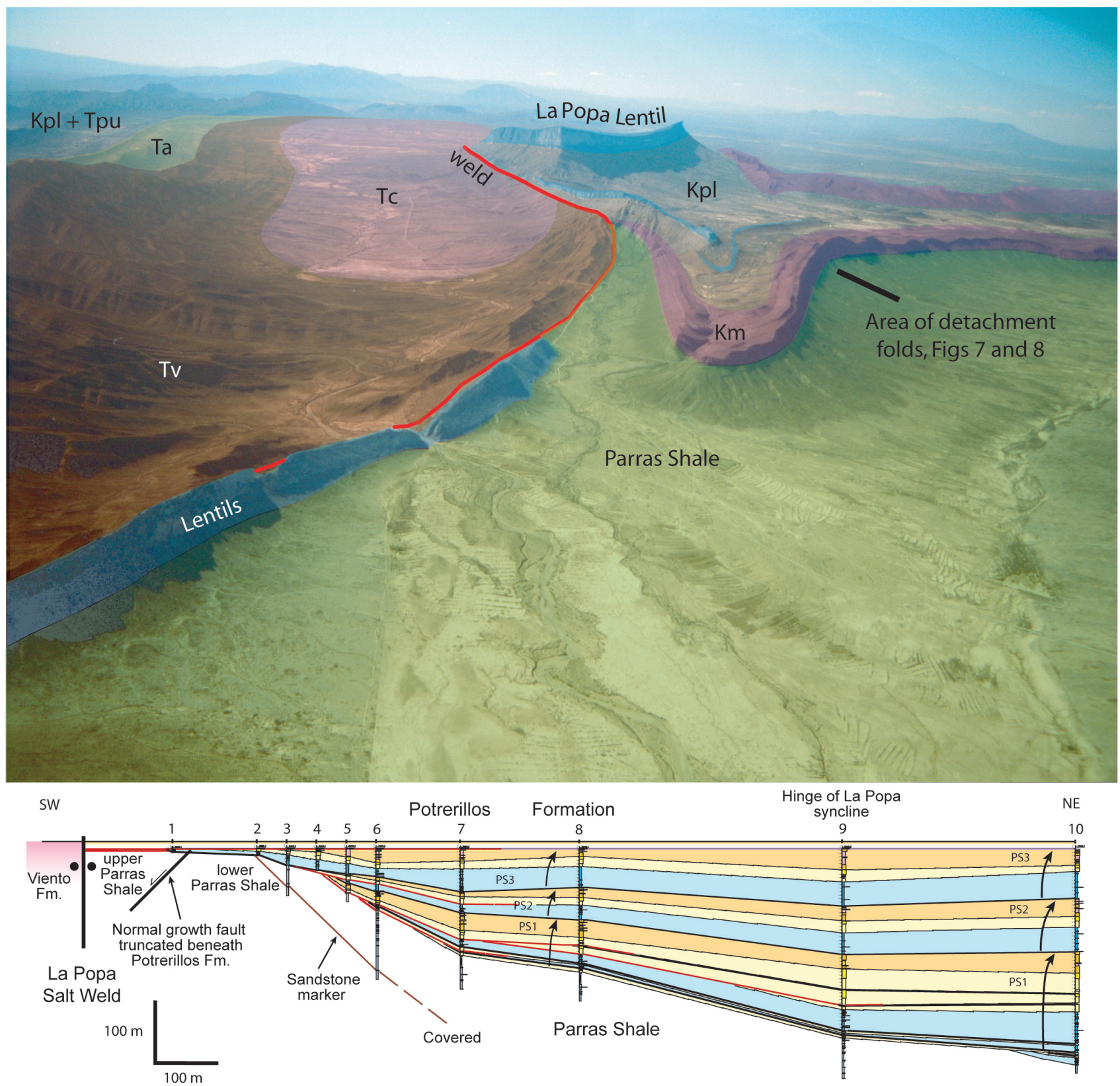

Figure 5. Oblique aerial photograph taken looking northwest along the La Popa salt weld (marked in red). The La Popa syncline is prominent north (right) of the weld, and the Carroza syncline is prominent south of the weld. The cliff face with prominent outcrops of detached fold-thrust features on the east flank of La Popa syncline is noted. Two of these structures are shown in Figure 7. This is also the area with the angular unconformity shown in Figure 8. The cross section is a series of measured sections along the west side of the La Popa syncline demonstrating the onlap relationships within the Muerto Formation. These data indicate that the La Popa salt wall (now weld) was active during the Muerto Formation deposition, while the adjacent La Popa syncline is a younger feature that apparently post-dates the Muerto Formation deposition. Abbreviations: Km = Muerto Formation; Kpl = lower Potrerillos Formation; Tpu= Upper Potrerillos Formation; Ta $=$ Adjuntas Formation, Tv $=$ Viento Formation, Tc $=$ Carroza Formation. La Popa Lentil refers to the large limestone body comprising the large cliff below the label. Photo courtesy of Bob Goldhammer. Cross section after Hon (2001).

basin area is recorded by a marked shift from carbonate to clastic deposition at the beginning of Campanian time. Marls of the Santonian Indidura Formation and the Campanian Parras Shale are both deep marine deposits, but the striking change in mineralogy at the beginning of the Campanian suggests that uplift and erosion had begun in the west (Gray et al., 2001; Gray and Lawton, 2008). Thick Campanian shales are prominent features of the Cretaceous Western Interior Seaway of the central U. S. A.; however, the transition to Campanian shale is more marked in NE Mexico due to the abrupt termination of carbonate deposition. The initial appearance of carbonate rock fragments in Parras Basin strata occurs in the upper Campanian Cañon del Tule Formation (Baker, 1970). These recycled carbonate 


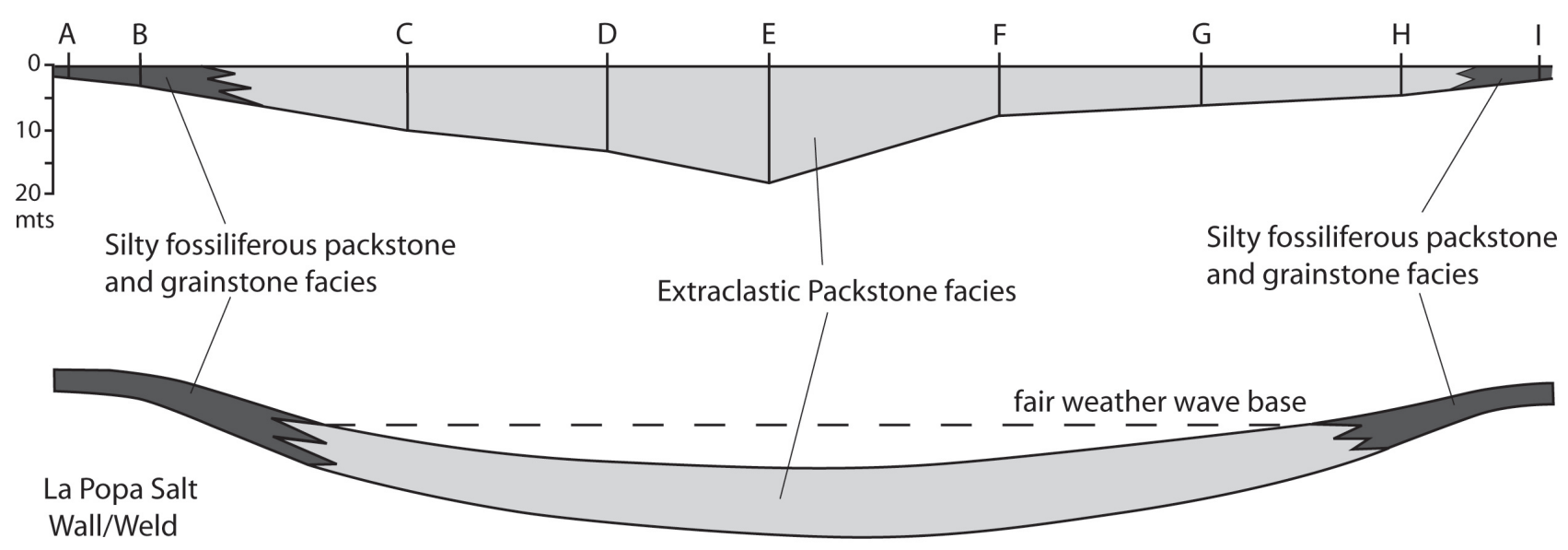

La Popa Syncline

Figure 6. Diagram of facies and thickness trends within one of the San Juan carbonate lentils in the upper Maastrichtian carbonate lentil in the Potrerillos Formation. This lentil was deposited across the La Popa syncline, and is composed of grainstone on the flanks of this syncline (Facies D) and packestone/ wackestone in the axis of the syncline (Facies E). This unit also thickens from 1-3 m on the flanks to $18 \mathrm{~m}$ in the center. Both of these observations indicate that the La Popa syncline was active during deposition of this unit, and comprises the earliest documented evidence for the age of inception of the La Popa syncline (from Druke, 2005).

lithic grains were derived from an uplifted hinterland that exposed Lower Cretaceous carbonates to the west (e.g., Lawton et al., 2009).

The oldest direct evidence for the onset of tectonic shortening is folding and faulting of the Muerto Formation in the La Popa Basin, east of La Popa syncline (Figure 7). These structures are east-west trending and have an overall appearance very similar to the $\mathrm{E}-\mathrm{W}$ trending structures in the Parras Basin. These structures are detached within the Campanian Parras Shale, although the detachment depth is not the same in all structures (Figure 7; Couch et al., 2004; Couch, 2005). Near La Popa syncline, these structures deform the lower Muerto Formation, but the uppermost Muerto Formation sands onlap the folds (Figure 8). These onlapping upper Muerto Formation beds in turn are slightly folded. The lower Potrerillos Formation overlaps these structures without evidence of E-W folding. These contractional structures are therefore early Maastrichtian in age. In the northern Parras Basin, Couch (2005) documented syntectonic growth on two east-west-trending folds, which she named the Los Tulillos fold complex. The main period of growth on the Los Tulillos structures occurred during deposition of the upper Maastrichtian Las Encinas Formation. Couch (2005) also demonstrated that fold growth appears to be younger to the south.

The E-W trending folds in the Parras Basin involve the entire stratigraphic section above the Parras Shale (Figure 2). Even the upper Paleocene growth strata in the Los Tulillos folds have been folded, indicating that contractional deformation in the Parras Basin continued into the Eocene.
In the eastern La Popa Basin, all of the E-W trending contractional structures appear to be early Maastrichtian. The E-W structures in western La Popa Basin have not been dated, although it appears that they involve only the lower Potrerillos Formation and hence could be slightly younger than the eastern structures. These relationships suggest a probable latest Cretaceous in age (Figure 3).

Eguiluz de Antuñano (2001) interpreted the end of folding in the Coahuila folded province at $39.5 \mathrm{Ma}$, based upon an angular unconformity in the adjacent Burgos Basin. Chavez-Cabello (2005) also placed an upper age limit on contractional deformation in the Coahuila folded belt using evidence from the late Eocene Monclova-Candela intrusive suite. He interpreted the $44 \mathrm{Ma}$ Mercado intrusive as a syntectonic pluton based upon a pronounced foliation within the body, while the slightly younger 42-39 Ma intrusives appear to be entirely post-tectonic. There are no preserved overlapping strata of late Eocene age or younger, so these textural data are the best extant constraints regarding the end of contractional deformation in the region.

\section{Relationship between halokinetic and contractional structures}

The oldest of structures in the Parras, La Popa, and southern Sabinas basins are related to the vertical movement of salt. These structures began to move by Aptian time, and appear to have formed as a result of sediment loading alone while the surrounding region was a very large 

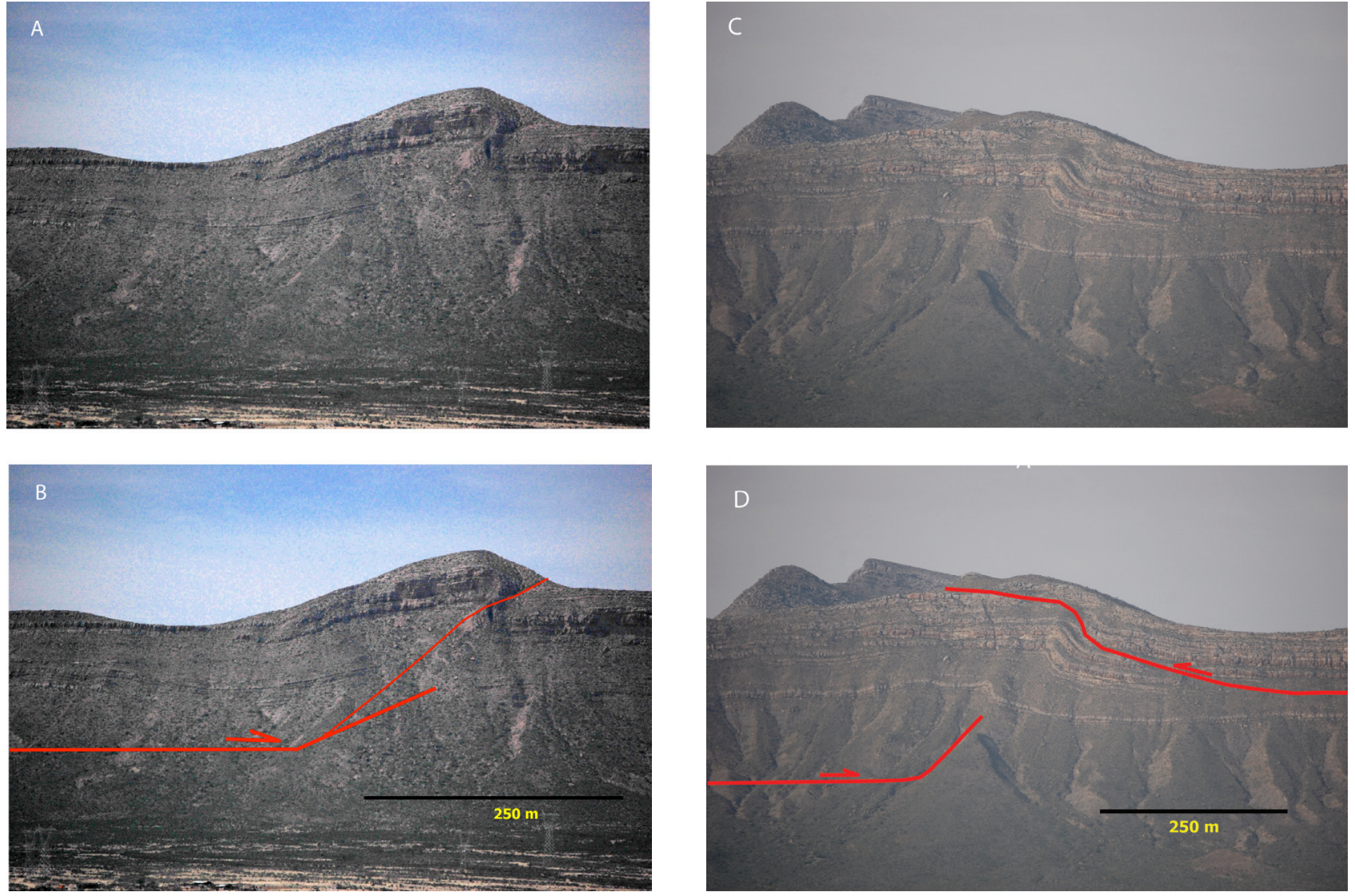

Figure 7. Photos and interpretive drawings of fold-thrust structures along the east face of the La Popa syncline. Both photos were taken looking west. North is on the right. (A) Northward-vergent fold-thrust structure cutting through the Parras Shale and lower and middle Muerto Formation sandstones. Cliff height is approximately $250 \mathrm{~m}$. (B) Fault interpretation for the fold-thrust structure in this cliff. Fault offset is approximately $20 \mathrm{~m}$. The interpreted detachment horizon is approximately $150 \mathrm{~m}$ below the base of the Muerto Formation. (C) An adjacent structure to that shown in A and B. This structure shows two different thrusts. The early thrust is south-vergent and cuts the Muerto Formation strata at a very low angle to bedding. This low-angle thrust detaches near the base of the Muerto Formation beds. It is folded by a younger fold-thrust structure with northward vergence. This second fault is interpreted to detach at approximately the same level as the fault shown in B.

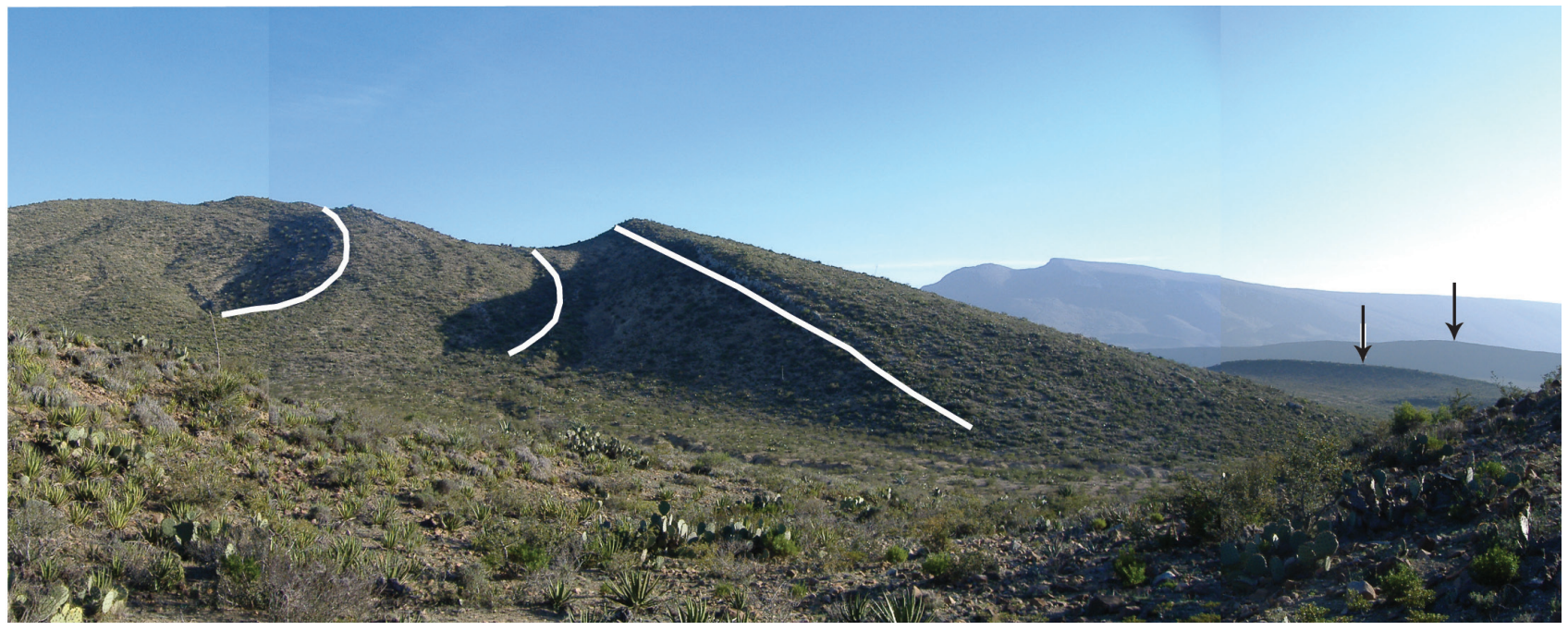

Figure 8. Photomosaic of upper Muerto Formation beds just west of the cliff face showing the local geometric relationships. White lines trace strongly folded lower and middle Muerto Formation beds and unfolded (in this view) uppermost Muerto Formation beds. Field mapping has shown that even these upper Muerto Formation beds are slightly affected by the east-west trending folds. Black arrows on the right note lower Potrerillos Formation beds that overlie these structures and are unaffected by the E-W trending folds. 
carbonate platform (Goldhammer, 1999; Lehmann et al., 1999). The diapiric structures in La Popa Basin do not appear to have a preferred orientation. The large salt weld along the northeast side of the basin, however, parallels the later contractional structures. The carbonates deposited in this platform are regionally quite uniform in thickness, indicating that regional tectonic deformation had not begun. Salt withdrawal continued into Eocene and possibly into Oligocene time (Gray et al., 2001). East-west trending contractional structures in eastern La Popa Basin were the next structures to form. These structures formed during a brief time of shortening in the early Maastrichtian.

Between late Maastrichtian and early Eocene time, both E-W and NW-SE trending structures were active, but the E-W folds were limited to the Parras Basin area, and the northwest-trending folds were active in the La Popa and southern Sabinas basins (Figure 2). We speculate that folding of the early Maastrichtian décollements in La Popa Basin by salt movement, as documented at La Popa syncline (Druke, 2005) and La Gavia anticline (Couch et al., 2004; Couch, 2005), may have prevented further development of detached structures within the Parras Shale, and limited subsequent deformation on E-W trending folds to the Parras Basin.

\section{Comparison of timing between NE Mexico and Sevier-Laramide province}

As noted earlier, the NW-SE and E-W trending folding in northeast Mexico was coeval in part with the late stages of both the Sevier and Laramide orogenies in the western U. S. A. The Late Cretaceous-Paleogene timing of deformation in Mexico is typically referred to as "Laramide" by most authors. We take exception to the usage of the term Laramide for several reasons. First and foremost is the implication that Laramide structures are characterized by the basementinvolved style present at the 'type' Laramide in southern Wyoming. Secondly, despite abundant references citing the Laramide orogeny as occurring over a very similar time period as deformation in northeast Mexico (e.g. Dickinson et al., 1988), a growing number of studies demonstrate that this distinctive structural style began earlier in the Cretaceous within the classic Laramide province than previously thought (DeCelles, 1986; Craddock et al., 1988; Barth et al., 2004; Jacques-Ayala et al., 2009). "Laramide-time" and "Sevier-time" are therefore essentially synonymous (Figure 9).

An obvious alternative would be to compare the Sierra Madre Oriental and Sabinas structures to the Sevier orogen. They are similar in style, especially in the areas where the Mexican foldbelts are strongly faulted. The late stages of the Sevier orogeny also overlap completely in time with the Mexican orogen (Craddock et al., 1988; Lawton and Trexler, 1991; Lawton et al., 1993) but the Sevier thrusting began in the Early Cretaceous, whereas the Sierra Madre Oriental

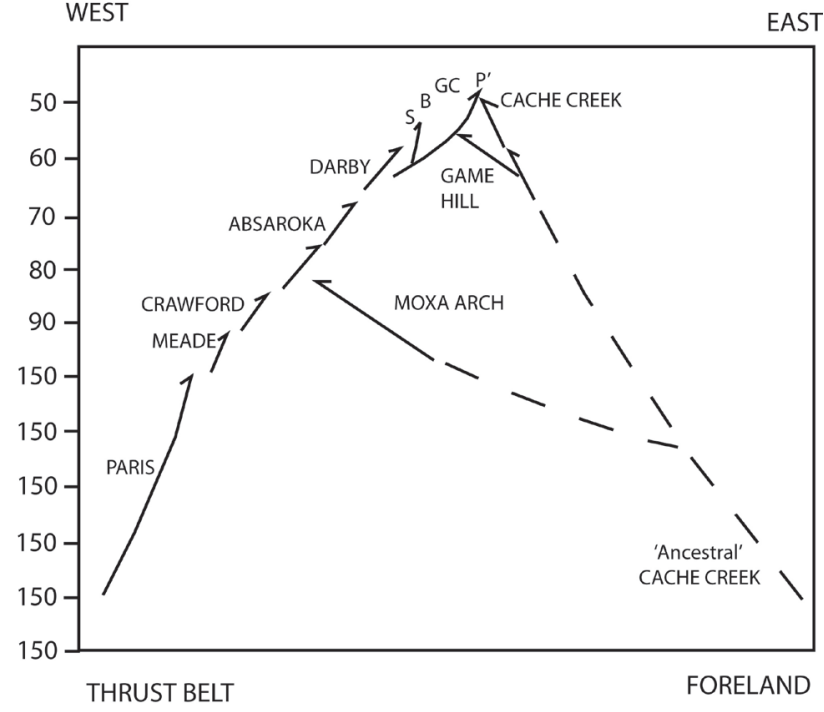

Figure 9. Diagram showing the coeval timing relationships of mostly thin-and thick-skinned features within the Idaho-Wyoming portion of the Sevier-Laramide system. Sevier structures are on the left, "thrust belt" side and Laramide structures are on the right, "foreland" side. Abbreviations: $\mathrm{S}=$ Shepherd thrust; $\mathrm{B}=$ Bear thrust; $\mathrm{GC}=$ Game Creek thrust; $\mathrm{P}^{\prime}$ = Prospect thrust. Synorogenic deposits are shown in parentheses. After Craddock et al. (1988).

and Sabinas structures were demonstrably not active until the latest Cretaceous. Although there are many similarities with the type Sevier and Laramide systems to the north, we think the differences in structural history within Mexico are significant enough to warrant retaining the term Hidalgoan orogeny as originally proposed by Guzmán and De Cserna (1963) by virtue of younger age and contrasting, salt- and shale-detached style of deformation in the northeastern Mexican cordillera. It is only by recognizing the kinematic and temporal differences between these areas that we will understand important variations in crustal type, crustal structure, stratigraphy, and plate interactions that drove these deformational events all along the margin of North America.

\section{Acknowledgments}

The authors would like to thank NMSU students Rachel Couch, Dominic Druke, Kevin Hon, David Shelley and Amy Weislogel, whose MS work was critical to this summary. The authors have benefited from discussions with many other colleagues regarding the geology of NE Mexico, in particular Samuel Eguiluz, Kate Giles, Bob Goldhammer, Rolando Peterson and James Wilson. Mark Rowan, Dante Morán and Gabriel Chávez Cabello are thanked for their thoughtful reviews. ExxonMobil Upstream Research Company is thanked for supporting many years of fieldwork and analyses and for permission to publish this work. 


\section{References}

Aranda-García, M., 1991, El segmento San Felipe del cinturón cabalgado, Sierra Madre Oriental, estado de Durango, México: Boletín de la Asociación Mexicana de Geólogos Petroleros, 41, 18-36.

Armstrong, R.L., 1968, Sevier orogenic belt in Nevada and Utah: Geological Society of America Bulletin, 79, 429-458.

Baker, R.A. III, 1970, Stratigraphy and sedimentology of the Cañon del Tule Formation (Upper Cretaceous), Parras Basin, Northeastern Mexico: Austin, Texas, U. S. A., The University of Texas at Austin, Ph. D. Thesis, $322 \mathrm{p}$.

Barth, A.P., Wooden, J.L., Jacobsen, C.E., Probst, K., 2004, U-Pb geochronology and geochemistry of the McCoy Mountains Formation, southern California: a Cretaceous retroarc foreland basin: Geological Society of America Bulletin, 116, 142-153.

Campa-Uranga, M.F., 1985, The Mexican thrust belt, in Howell, D.G. (ed.), Tectonostratigraphic terranes of the circum-Pacific: Council for Energy and Mineral Resources, Earth Science Series, 299-313.

Chávez-Cabello, G., 2005, Deformación y magmatismo Cenozoicos en el sur de la cuenca Sabinas, Coahuila, México: México, D.F., Universidad Nacional Autónoma de México, Ph. D. Thesis, 313 p.

Couch, R.D., 2005, Style, timing, and uplift history of the frontal Sierra Madre Oriental fold belt determined through analysis of growth strata and vitrinite reflectance: Las Cruces, New Mexico, U.S.A., New Mexico State University, M.S. Thesis, 243 p.

Couch, R.D., Lawton, T.F., Gray, G.G., Rowan, M.G., Vega, F.J., 2004, Relative ages of detachment folding and basin inversion, foreland basin system of Sierra Madre Oriental, northeastern Mexico: Geological Society of America Abstracts with Programs, 36, 88.

Craddock, J.P., Kopania, A.A., Wiltschko, D.V., 1988, Interaction between the northern Idaho-Wyoming thrust belt and bounding basement blocks, central western Wyoming, in Schmidt, C.J., Perry, W.J. Jr. (eds.), Interaction of the Rocky Mountain foreland and the Cordilleran Thrust Belt: Geological Society of America Memoirs, 171, 333-352.

De Cserna, Z., 1956, Tectonica de la Sierra Madre Oriental de México entre Torreón y Monterrey, in 20th International Geological Congress: México, D.F., 87 p.

De Cserna, Z., 1971, Taconian (early Caledonian) deformation in the Huasteca structural belt of eastern Mexico: American Journal of Science, 271, 544-550.

DeCelles, P.G., 1986, Sedimentation in a tectonically partitioned, nonmarine foreland basin: the Lower Cretaceous Kootenai Formation, southwestern Montana: Geological Society of America Bulletin, 97, 911-931.

Dickinson, W.R., Klute, M.A., Hayes, M.J., Janecke, S.U., Lundin, E.R., McKittrick, M.A., Olivares, M.D., 1988, Paleogeographic and paleotectonic setting of Laramide sedimentary basins in the central Rocky Mountain region: Geological Society of America Bulletin, 100, 1023-1039.

Dillman, G.J., 1985, Structural investigation and tectonic history of the central Parras basin, Saltillo, Coahuila, Mexico: Houston, Texas, U. S. A., University of Houston, M.S. Thesis, 293 p.

Drewes, H., 1988, Development of the foreland zone and adjacent terranes of the Cordilleran orogenic belt near the U.S.-Mexican border, in Schmidt, C.A., Perry, W.J., Jr., (eds.), Interaction of the Rocky Mountain foreland and the Cordilleran thrust front: Geological Society of America Memoir, 171, 447-463.

Druke, D.C., 2005, Sedimentology and stratigraphy of the San Jose lentil, La Popa basin, Mexico and implications for carbonate development in a tectonically influenced salt basin: Las Cruces, New Mexico, U. S. A., New Mexico State University, M.S. Thesis, 132 p.

Eguiluz de Antuñano, S., 2001, Geologic evolution and gas resources of the Sabinas basin in Northeastern Mexico, in Bartolini, C., Buffler, R.T., Cantú-Chapa, A. (eds.), The western Gulf of Mexico basin: Tectonics, sedimentary basins, and petroleum systems: American Association of Petroleum Geologists Memoir, 75, 241-270.

Giles, K.A., Lawton, T.F., 1999, Attributes and evolution of an exhumed salt weld, La Popa Basin, Northeastern Mexico: Geology, 27, 323-326.

Giles, K.A., Lawton, T.F., 2002, Halokinetic sequence stratigraphy adjacent to El Papalote diapir, La Popa basin, northeastern Mexico: American Association of Petroleum Geologists Bulletin, 86, 823-841.

Goldhammer, R.K., 1999, Mesozoic sequence stratigraphy and paleogeographic evolution of northeastern Mexico, in Bartolini, C., Wilson, J.L., Lawton, T.F. (eds.), Mesozoic sedimentary and tectonic history of north-central Mexico: Geological Society of America Special Paper, 340, 1-59.

Gray, G.G., Lawton, T.F., 2008, Evidence for basement type distribution using zircon $\mathrm{U} / \mathrm{Pb}$ age spectra from Jurassic and Cretaceous sandstones, greater Monterrey area, Mexico (abstract): Geological Society of American Abstracts with Programs, 40, 199.

Gray, G.G., Pottorf, R.J., Yurewicz, D.A., Mahon, K.I., Pevear, D.R., Chuchla, R.J., 2001, Thermal and chronological record of syn- to post-Laramide burial and exhumation, Sierra Madre Oriental, Mexico, in Bartolini, C., Buffler, R.T., Cantú-Chapa, A. (eds.), The western Gulf of Mexico Basin: Tectonics, sedimentary basins, and petroleum systems: American Association of Petroleum Geologists Memoir, 75, 159-181.

Guzmán, E.J., De Cserna, Z., 1963, Tectonic history of Mexico, in Childs, O.E., Beebe, B.W. (eds.), Backbone of the Americas - tectonic history from pole to pole: American Association of Petroleum Geologists Memoir, 2, 113-129.

Hon, K., 2001, Salt-influenced growth-stratal geometries and structure of the Muerto Formation adjacent to an ancient secondary salt weld, La Popa Basin, Nuevo Leon, Mexico: Las Cruces, New Mexico, U. S. A., New Mexico State University, M.Sc. Thesis, 97 p.

Jacques-Ayala, C., Barth, A.P., Wooden, J.L., Jacobson, C.E., 2009, Provenance and $\mathrm{U}-\mathrm{Pb}$ geochronology of the Upper Cretaceous El Chanate Group, northwest Sonora, Mexico, and its tectonic significance: International Geology Review: 51, 1051-1077.

Kulik, D.M., Schmidt, C.J., 1988, Region of overlap and styles of interaction of Cordilleran thrust belt and Rocky Mountain foreland, in Schmidt, C A., Perry, W.J. Jr. (eds.), Interaction of the Rocky Mountain foreland and the Cordilleran thrust front: Geological Society of America Memoir, 171, 75-98.

Laudon, R.C., 1984, Evaporite diapirs of the La Popa basin, Nuevo León, México: Geological Society of America Bulletin, 95, 1219-1225.

Lawton, T.F., Trexler, J.H. Jr., 1991, Piggyback basin in the Sevier orogenic belt, Utah: implications for development of the thrust wedge: Geology, 19, 827-830.

Lawton, T.F., 2008, Laramide sedimentary basins, in Miall, A. (ed.) The Sedimentary Basins of the United States and Canada: Amsterdam, The Netherlands, Elsevier, 429-450.

Lawton, T.F., Bradford, I.A., Vega, F.J., Gehrels, G.E., Amato, J.M., 2009, Provenance of Upper Cretaceous-Paleogene sandstones in the foreland basin system of the Sierra Madre Oriental, northeastern Mexico, and its bearing on fluvial dispersal systems of the Mexican Laramide Province: Geological Society of America Bulletin, 121, 820-836.

Lawton, T.F., Talling, P.J., Hobbs, R.S., Trexler, J.H. Jr., Weiss, M.P., Burbank, D.W., 1993, Structure and stratigraphy of Upper Cretaceous and Paleocene strata (North Horn Formation), eastern San Pitch Mountains, Utah - Sedimentation at the front of the Sevier orogenic belt: U. S. Geological Survey Professional Paper, 1787-II, $33 \mathrm{p}$.

Lawton, T.F., Vega, F.J., Giles, K.A., Rosales-Dominguez, C., 2001, Stratigraphy and origin of the La Popa basin, Nuevo Leon and Coahuila, Mexico, in Bartolini, C., Buffler, R.T., Cantú-Chapa, A. (eds.), Mesozoic and Cenozoic evolution of the western Gulf of Mexico basin: Tectonics, sedimentary basins and petroleum systems: American Association of Petroleum Geologists Memoir, $75,219-240$

Lehmann, C., Osleger, D.A., Montañez, I.P., Sliter, W., Arnaud-Vanneau, A., Banner, J., 1999, Evolution of Cupido and Coahuila carbonate platforms, Early Cretaceous, northeastern Mexico: Geological Society of America Bulletin, 111, 1010-1029. 
McBride, E.F., Weidie, A.E., Wolleben, J.A., Laudon, R.C., 1974, Stratigraphy and structure of the Parras and La Popa basins, northeastern Mexico: Geological Society of America Bulletin, 85, 1603-1622.

Padilla y Sánchez, R.J., 1985, Las estructuras de la Curvatura de Monterrey, Estados de Coahuila, Nuevo León, Zacatecas y San Luís de Potosí: Revista del Instituto de Geología, Universidad Nacional Autónoma de México, 6, 1-20.

Prost, G., Aranda, M., 2001, Tectonics and Hydrocarbon Systems of the Veracruz Basin, Mexico, in Bartolini, C., Buffler, R.T., Cantú-Chapa, A. (eds.), The western Gulf of Mexico Basin: Tectonics, sedimentary basins, and petroleum systems: American Association of Petroleum Geologists Memoir, 75, 271-291.

Prost, G., Marrett, R., Aranda, M., Eguiluz, S., Galicia, J., Banda, J., 1994, Deformation history of the Sierra Madre Oriental, Mexico, and associated hydrocarbon generation-preservation (abstract): Houston, Texas, First Joint AAPG/AMPG Research Conference Abstracts, 3.

Rowan, M.G., Lawton, T.F., Giles, K.A., Ratliffe, R.A., 2003, Near-salt deformation in La Popa basin, Mexico, and the northern Gulf of Mexico: a general model for passive diapirism: American Association of Petroleum Geologists Bulletin, 87, 733-756.

Shelley, D.C., Lawton, T.F., 2005, Sequence stratigraphy of tidally influenced deposits in a salt-withdrawal minibasin: Upper sandstone member of the Potrerillos Formation (Paleocene), La Popa Basin, northeastern Mexico: American Association of Petroleum Geologists Bulletin, 89, 1157-1179.

Soegaard, K., Ye, H., Halik, N., Daniels, A., Arney, J., Garrick, S., 2003, Stratigraphic evolution of latest Cretaceous to Early Tertiary Difunta foreland basin in northeast Mexico: Influence of salt withdrawal on tectonically induced subsidence by the Sierra Madre Oriental fold and thrust belt, in Bartolini, C., Buffler, R.T., Blickwede, J. (eds.), The Circum-Gulf of Mexico and the Caribbean: Hydrocarbon habitats, basin formation and plate tectonics: American Association of Petroleum Geologists Memoir, 79, 364-394.
Vega-Vera, F.J., Mitre-Salazar, L.M., Martínez, E., 1989, Contribución al conocimiento de la estratigrafía del grupo Difunta (Cretácico superior-Terciario) en el noreste de México: Revista del Instituto de Geología, Universidad Nacional Autónoma de México, 8, 179-187.

Weidie, A.E., Murray, G.E., 1967, Geology of the Parras Basin and adjacent areas of northeastern Mexico: American Association of Petroleum Geologists Bulletin, 51, 678-695.

Weislogel, A.L., 2001, The influence of diapirism and foreland evolution on the depositional system, stratigraphy, and petrology of the Maastrichtian Muerto Formation, La Popa Basin, Mexico: Las Cruces, New Mexico, U. S. A., New Mexico State University, M.Sc. Thesis, $242 \mathrm{p}$.

Ye, H., 1997, The arcuate Sierra Madre Oriental orogenic belt, NE Mexico: Tectonic infilling of a recess along the southwestern North American continental margin, in Soegaard, K., Giles, K., Vega, F.J., Lawton, T.F. (eds.), Structure, Stratigraphy, and Paleontology of Late Cretaceous-Early Tertiary Parras-La Popa foreland basin near Monterrey, Mexico: Dallas, Texas, U. S. A., Annual Meeting of the American Association of Petroleum Geologists Field Trip Guide 10, 85-115.

Manuscript received: July 9, 2009.

Corrected manuscript received: May 12, 2010.

Manuscript accepted: June 11, 2010. 